\title{
INNOVATING THE HOSPITALAR SERVICE WITH FOCUS IN KAIZEN METHOD
}

\footnotetext{
${ }^{1}$ Thiago Jose Barbosa Dantas; ${ }^{2}$ Flávio de São Pedro Filho; ${ }^{3}$ Valeria Arenhardt; ${ }^{4}$ Ademar Roque Lorenzon; ${ }^{5}$ Marcelo José Peres Gomes da Silva, ${ }^{6}$ Norma Maria Coelho Vieira

${ }^{1}$ Is Undergraduate Management Student, Federal University of Rondônia, Brazil.

E-mail: t.dantas@outlook.com

${ }^{2}$ Post-Doctoral researcher in Management and Economics at the University of Beira Interior, Portugal.

Doctor of Business Management from the Universidad Autónoma de Asunción, Paraguay. Doctor of

Administration from the University of São Paulo, Brazil. Coordinator of the Research Group on

Management of Innovation and Technology (GEITEC), Brazil. E-mail: flavio1954@gmail.com

${ }^{3}$ Doctoral researcher in Environmental Technology at the University of Ribeirão Preto. Contributor of the Research Group on Management of Innovation and Technology Management (GEITEC), Brazil.

E-mail: valeria.arenhardt@ifro.edu.br

${ }^{4}$ Lawyer and entrepreneur in the city of Pimenta Bueno, State of Rondônia, Brazil. Contributor of the

Research Group on Management of Innovation and Technology (GEITEC), Brazil. E-mail:

roquelorenzon@hotmail.com

${ }^{5}$ Specialist in Computer Networks and Data Communications at the State University of Londrina (UEL). Contributor of the Research Group on Management of Innovation and Technology (GEITEC), Brazil. E-mail: engcompmarcelo@hotmail.com

${ }^{6}$ Master's Degree Student in Environmental Sciences from the University of Taubaté (UNITAU). Contributor of the Research Group on Management of Innovation and Technology (GEITEC), Brazil.

E-mail: coelho.norma@gmail.com
}

\begin{abstract}
The Hospitals of the Porto Velho city require improvements in their physical structures, as well as the improvement of services given to the population. This is about a innovation using the Kaizen method in the Diagnostics image sector unit of a hospital located in the city of Porto Velho, Capital of Rondônia State, in Brazil. This study is based on the Contingency Theory, dealing with environmental issues that impact the development of the activities studied, meeting the concepts of PDCA Cycle and innovation as it has been treated in Nascimento et al (2011) and Pizzani et al (2012). The general objective is the study of the forms to apply the
\end{abstract}


Kaizen method in the Diagnostic image sector of a hospital; treating specific objective the examinations of procedures of study (1) To compare the results between the periods before and after the implementation of the Kaizen method (2) and indicate measures for innovation in the continuous improvement process of studied sector (3). The preparation followed by the Case Study Method, supported in literature review; as procedures were carried out in situ visits, interviews, observation data collection and selection of data, and other required by the method. As a result today the industry develops the evaluation and check the procedures adopted, thereby seeking to improve continuously. This study is of interest of those who carried out the research and those involved because it results in excellent production of quality tests.

Keywords: Administration. Management. Kaizen. Innovation. Quality.

\section{INTRODUCTION}

This work deals with the implementation of the Kaizen method in the diagnostic imaging sector of a hospital in the city of Porto Velho, Rondônia State Capital, in Brazil. What is observed in this scenario is that the predominant need for studies aimed at continuous improvement when it comes to quality in examinations and in the care of patients treated in this unit and in particular those related to diagnostic tests for image, object of this research. To do a survey of the quality of the machines and the material used in the examinations is necessary. This task will follow this reasoning, first stating the goals and then trying on a theoretical and conceptual review that allows the interpretation of the state of the art; a methodology will be considered and the results will be discussed here, followed by the results, conclusion and references. Given this reality, this study aims to answer the following research question: What are the characteristics to improve the results of their tests? Seeking to answer this question it is accepted here as a general objective to study the ways of applying Kaizen method in diagnostic imaging sector of a hospital; and specific objectives to survey the examinations of performing procedures on the platform in the study (1) compare the results between the periods before and after the implementation of the Kaizen method (2), and indicate measures for innovation in the continuous improvement process the studied sector (3).

\section{LITERATURE REVIEW}

Kaizen is considered the most important concept of Japanese management is based on continuous improvement, this improvement is linked to various aspects involving the work environment, involving people, environment and means to carry out the tasks. In this sense, the review in question will address first the concepts of contingency theory, in a second time the application of Kaizen then about the innovation in this segment and finally address the application of methods that assist the implementation of Kaizen, as PDCA.

\subsection{Contingency Theory}

Bibliographic surveys in Chiavenato (2014) point out that the Contingency Theory is the latest current assumes that management is relative and situational, that is, it depends on organization of environmental and technological circumstances. For Bächtold (2012), the Contingency Theory points out that there is nothing absolute or universal principles in the organization. However, its efficiency depends on the structure and procedures adopted by this organization. Given the above, Santos (2014) states that in the Contingency theory there is only one way for companies to organize, but a range of possibilities that before changing environments where uncertainties are nearly zero, the activities will be developed more effectively through a centralized set of decisions, and distinction between daily work responsibilities. On the other hand, in unstable environments and possibilities of constant innovation, there is further development of organic organizations and that these no greater diversification of tasks, less formal positions in the hierarchy and planning. In other words, the most stable organizations apply the classical theory while in unstable organizations would be effective the Theory of Human Relations.

In the study platform, production processes occur on demand, which according to the health condition evaluation needs of patients specific tests will be required, such as diagnosis of the imaging, where we can observe the 
interaction with Theory Contingent, since these processes will receive interference from internal and external environments as will be seen in the development of the text.

\subsection{Kaizen Concept}

According Chiavenato (2014) Kaizen is a word that is a process management and business culture in the sense of continuous improvement, employee involvement and commitment of all members of the organization. Kaizen is a philosophy of continuous improvement of the members of an organization, so that their tasks are enhanced every day.

Literature made in Asuncion et al (2013) describes the Kaizen is the most important management tool used in Japan. With the success of Japanese growth concept has gained visibility in other countries, where it has been used successfully, as it brings with it other methods like Kambam, Just in time, zero defect and suggestion system, among many others. The greatest example of successful implementation of Kaizen is also the pioneer in the application of the example of Toyota, which has its system focused on continuous improvement, with the help of Kaizen Toyota developed its management model, as well as improved their production processes, while able to reduce costs and waste in production and also developed its employees, a key part in the success of any production process. This is another point of success of Kaizen, the development of its employees, from those who are part of the operational area until those in executive positions.

Kaizen, has three key elements, the standardization of processes, in order to minimize variation thereof, thereby reducing the possibility of error; the five-S which serves as an educational process where prizes by the use (Seiri), sorting (Seiton), cleaning (Seisou), hygiene (Seiketsu) and self-discipline (Shitsuke) and ultimately waste disposal aimed at elimination of all elements that lead to waste in carrying out activities such as waiting time, inadequate processes between others. Chiavenato (2014) meant that Kaizen is a way of thinking based on ten principles that follow detailing their applicability in the study in Table 1.

\begin{tabular}{|l|l|}
\hline \multicolumn{1}{|c|}{ Principles } & \multicolumn{1}{c|}{ Detailing } \\
\hline $\begin{array}{l}\text { Promote continuous } \\
\text { improvements }\end{array}$ & $\begin{array}{l}\text { By encouraging participation in training, Symposia, } \\
\text { Conferences that bring a greater burden of knowledge to } \\
\text { professionals. }\end{array}$ \\
\hline Emphasize customers & humanized care \\
\hline Acknowledge problems openly & $\begin{array}{l}\text { Analyze what actually reduces the quality of care, so as to } \\
\text { act in a way ... }\end{array}$ \\
\hline $\begin{array}{l}\text { Promote open and frank } \\
\text { discussion }\end{array}$ & $\begin{array}{l}\text { Exposing the problems experienced by the sector to the } \\
\text { most senior levels, in the search for practical and quick } \\
\text { solutions. }\end{array}$ \\
\hline $\begin{array}{l}\text { Manage projects through cross- } \\
\text { functional teams }\end{array}$ & $\begin{array}{l}\text { Creating a radiology committee, which seeks } \\
\text { improvements for both the industry and for professionals } \\
\text { and especially for the public attended. }\end{array}$ \\
\hline $\begin{array}{l}\text { Encourage relationships } \\
\text { between people }\end{array}$ & $\begin{array}{l}\text { Hold regular meetings in order to discuss new } \\
\text { technologies and new ways to improve the sector's } \\
\text { performance. }\end{array}$ \\
\hline Developing self-discipline & $\begin{array}{l}\text { Through the development of protocols to be followed in } \\
\text { pursuing the realization of the tasks in the most correct } \\
\text { and dynamic way. }\end{array}$ \\
\hline $\begin{array}{l}\text { Communicate and inform all } \\
\text { people }\end{array}$ & $\begin{array}{l}\text { Use billboard, corporate e-mail, social networking groups, } \\
\text { where everyone can have quick and easy access to } \\
\text { activities in the sector. }\end{array}$ \\
\hline $\begin{array}{l}\text { Train intensely and empower all } \\
\text { people }\end{array}$ & $\begin{array}{l}\text { Develop refresher courses, exchange between entities } \\
\text { that assist the development of the techniques used in } \\
\text { carrying out the activities. }\end{array}$ \\
\hline
\end{tabular}

Table 1: Breakdown of the principles applied to study platform Source: Prepared by the authors based on Chiavenato (2014) 


\subsection{Concept of diagnostic imaging and of innovative processes}

Based on the concepts of Kaizen philosophy, the processes of innovation and continuous improvement in the diagnostic sector imaging, are necessary changes ranging from the type of relationship with patients, using the latest materials, because through them will be held in the continuous improvement process. In the study platform is possible to list some actions regarding the improvement of processes, such as shown in Table 2.

\begin{tabular}{|l|l|}
\hline \multicolumn{1}{|c|}{ Actions } & \multicolumn{1}{c|}{ Detailing } \\
\hline $\begin{array}{l}\text { Activities and dynamics } \\
\text { that allow better } \\
\text { interaction between } \\
\text { technicians and } \\
\text { patients. }\end{array}$ & $\begin{array}{l}\text { Use of humanized care, where staff makes use of informal } \\
\text { conversations with the patient's family, use of toys, costumes } \\
\text { and other tricks that may reassure the patient and family. }\end{array}$ \\
\hline $\begin{array}{l}\text { Use of first-line } \\
\text { materials in the } \\
\text { examinations }\end{array}$ & $\begin{array}{l}\text { Using the best quality materials available on the market, } \\
\text { resulting in better image quality. }\end{array}$ \\
\hline Machinery renovation & $\begin{array}{l}\text { For quality service, the implementation of means that it is } \\
\text { necessary, one is the renewal of machinery. }\end{array}$ \\
\hline $\begin{array}{l}\text { Refresher courses for } \\
\text { industry professionals }\end{array}$ & $\begin{array}{l}\text { Every day are launched new technologies, it is extremely } \\
\text { important to maintaining knowledge of professionals working in } \\
\text { the sector. }\end{array}$ \\
\hline $\begin{array}{l}\text { Industry expansion, } \\
\text { providing more comfort } \\
\text { to patients and } \\
\text { technicians }\end{array}$ & $\begin{array}{l}\text { Today the sector does not offer a rest room for technicians, as } \\
\text { well as a waiting room for patients, which leads to many } \\
\text { complaints. }\end{array}$ \\
\hline
\end{tabular}

Table 2: Breakdown of actions to improve processes Source: Prepared by the authors

These are just some of the points that help to improve the service, which will be reduced the amount of repeated examinations by malfunctioning machines, poor quality of materials used in clinical exams and other. These are questions that can lead to further problems, both for patients and for industry professionals, because the greater the number of tests that a patient is, the greater the amount of ionizing radiation received by this, radiation that can change the cell growth, which in turn influences the appearance of cancer cells e.g.

\subsection{Definition about use of PDCA to complement the Kaizen Philosophy}

For Silva and Sartori (2014) PDCA cycle is a set of sequenced actions in a pre-established order, where $\mathrm{P}$ (Planning), D (Do), C (Check) and A (Act). Each step is described as follows, $P$ (plan) is the stage where the shortcomings and failures to prepare a plan of action are identified, the $D$ (do), is nothing more than the implementation of the plan, $\mathrm{C}$ (Check) is an assessment of the actions carried out previously and finally the A (Act), which is the standardization and display of the results for the organization.

Acting in conjunction with the PDCA Kaizen philosophy preaches a renewal continues in the processes and procedures of the organization, making it the default so that even with employee turnover in the industry, which works by service level, the activities have the same quality always.

The Kaizen philosophy is linked not only to continuous improvement, plus the achievement of specific results, such as the elimination of waste, passing from the material time, effort, in addition to raising the quality of services provided. Such a philosophy also teaches that nothing in the environment is static, everything can be serviced and have their cases reviewed.

\section{METHODOLOGY}

This first survey was the bibliographical type to Pizzani et al (2012) this is the literature review of the main guiding theories of scientific work, and may be literature call and can be performed in books, journals, newspaper articles, internet sites, etc. Among the literature review of goals has the possibility of providing learning about a particular area of knowledge, such as Kaizen, and facilitate the identification of methods to be used by the researcher and provide subsidies for the introduction and writing work discussion.

This research was also developed using case study, since it is characterized by an in-depth study of the study 
platform. Still was the type of field study which seeks the deepening of a specific reality, done mostly through observation of the reality of the situation in loco. The instrument of data collection will be the semi-structured interview in which researchers carry out a previous script of questions in order to meet the research objectives. The data collected will be compared by the theory and practice held in the data survey.

Moreover, regarding the presentation and discussion of the results of the research will be demonstrated by the theoretical basis of the trends and themes of counterpoints related to strategic planning and the goals established in starting mode for this search. Finally, and not least, a proposal for measures for innovation in the improvement process will be presented remains of the studied sector.

\section{Figure 1: Diagram of the methodological procedures.} Source: Prepared by the authors.
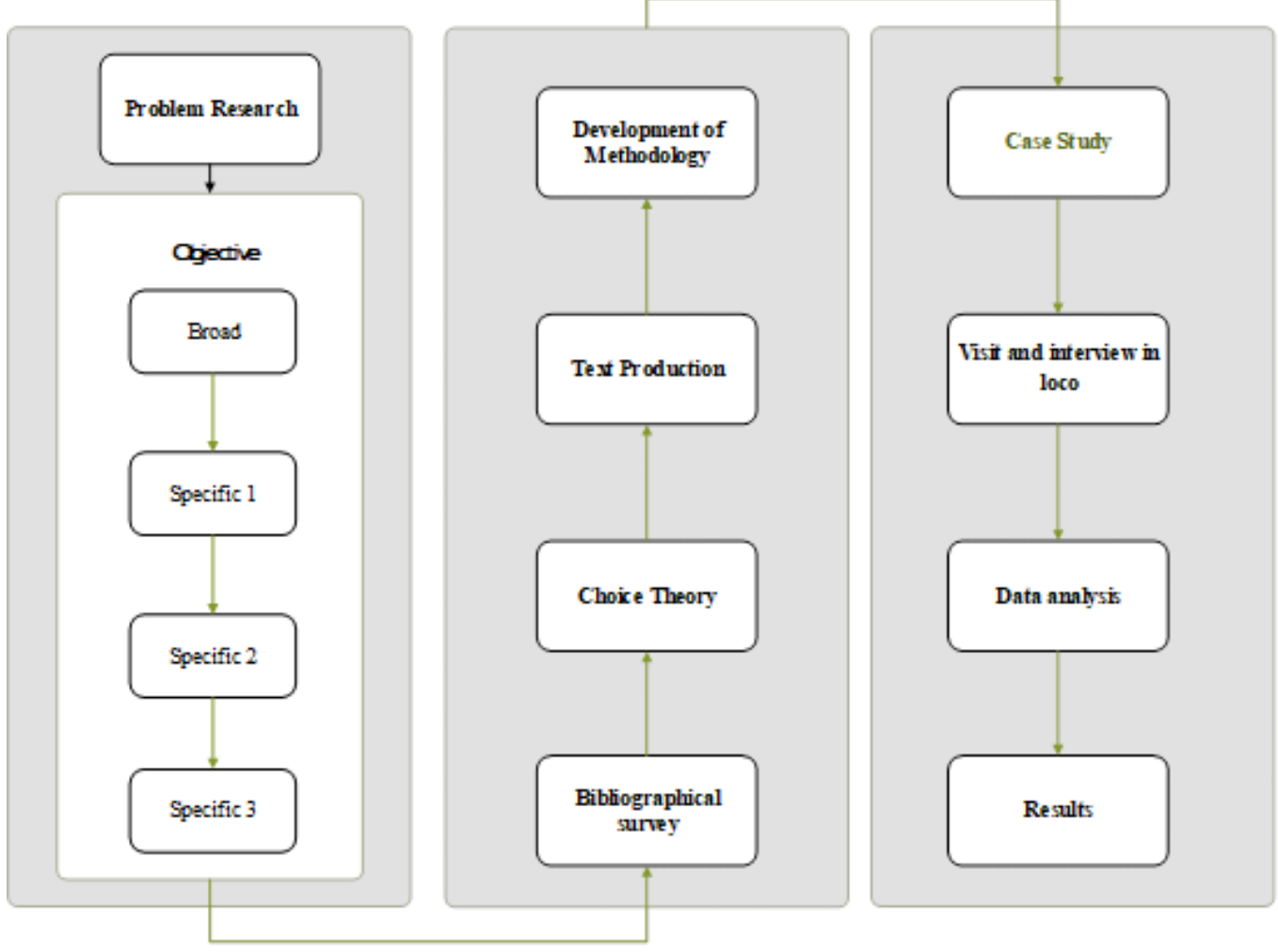

\begin{tabular}{|l|l|}
\hline \multicolumn{1}{|c|}{$\begin{array}{c}\text { Adopted } \\
\text { procedures }\end{array}$} & \multicolumn{1}{c|}{ Descriptive procedures } \\
\hline $\begin{array}{l}\text { 1. Research } \\
\text { Problem }\end{array}$ & $\begin{array}{l}\text { The research problem it is a question that will pervade throughout the research, is part } \\
\text { of the literature, the methodology, the application of instruments for data collection, } \\
\text { data analysis and especially the response to the objectives and achieving the same in } \\
\text { achieving the scientific processes. }\end{array}$ \\
\hline 2. Objectives & $\begin{array}{l}\text { The objectives are considered the basis for the research. These are the way forward } \\
\text { to answer the question of the research problem. To best be understood were broken } \\
\text { down into general purpose and specific objectives. These finally direct the technical } \\
\text { progress of research. }\end{array}$ \\
\hline $\begin{array}{l}\text { 3. Bibliographic } \\
\text { survey }\end{array}$ & $\begin{array}{l}\text { The literature is to conduct an overview of the subject in scientific publications of } \\
\text { researchers in discussion in order to understand how these thinkers understand the } \\
\text { phenomenon of Master Production Planning (PMP). In this item we were presented } \\
\text { the main articles published in Brazil since 2010. }\end{array}$ \\
\hline $\begin{array}{l}\text { 4. Development } \\
\text { of Methodology }\end{array}$ & $\begin{array}{l}\text { The methodology is how the survey was conducted, developed and implemented at } \\
\text { their place of fulfillment. It is in this item that were addressed the question of literature, } \\
\text { the case study to be a specific and field study reality as the students were in search } \\
\text { results. }\end{array}$ \\
\hline
\end{tabular}




\section{Responses to goals}

Finally, after the literature, the construction of the methodology and data analysis. The answer to the objectives and the problem of research is key point to verify that the data collected and analyzed are sufficient to address these questions. This point is crucial to the completion of the survey.

\section{Table 3: Breakdown of the procedures adopted Source: Prepared by the authors}

\section{RESULTS AND DISCUSSION}

The study was developed in a hospital in the city of Porto Velho, State of Rondônia, where a survey conducted on site it was possible to follow the processes developed in the diagnostic sector imaging, where it was realized that the procedures adopted are developed in an organized way, but with limitations that affect the quality of both the service and the quality of exams. The industry processes are developed in three stages: registration (1); the examination (2); delivery of results (3). In Figure 2 and Table 4 are shown the flow chart and description respectively of the production processes of the study platform.

Figure 2: Flowchart of procedures for the examinations. Source: Prepared by the authors.

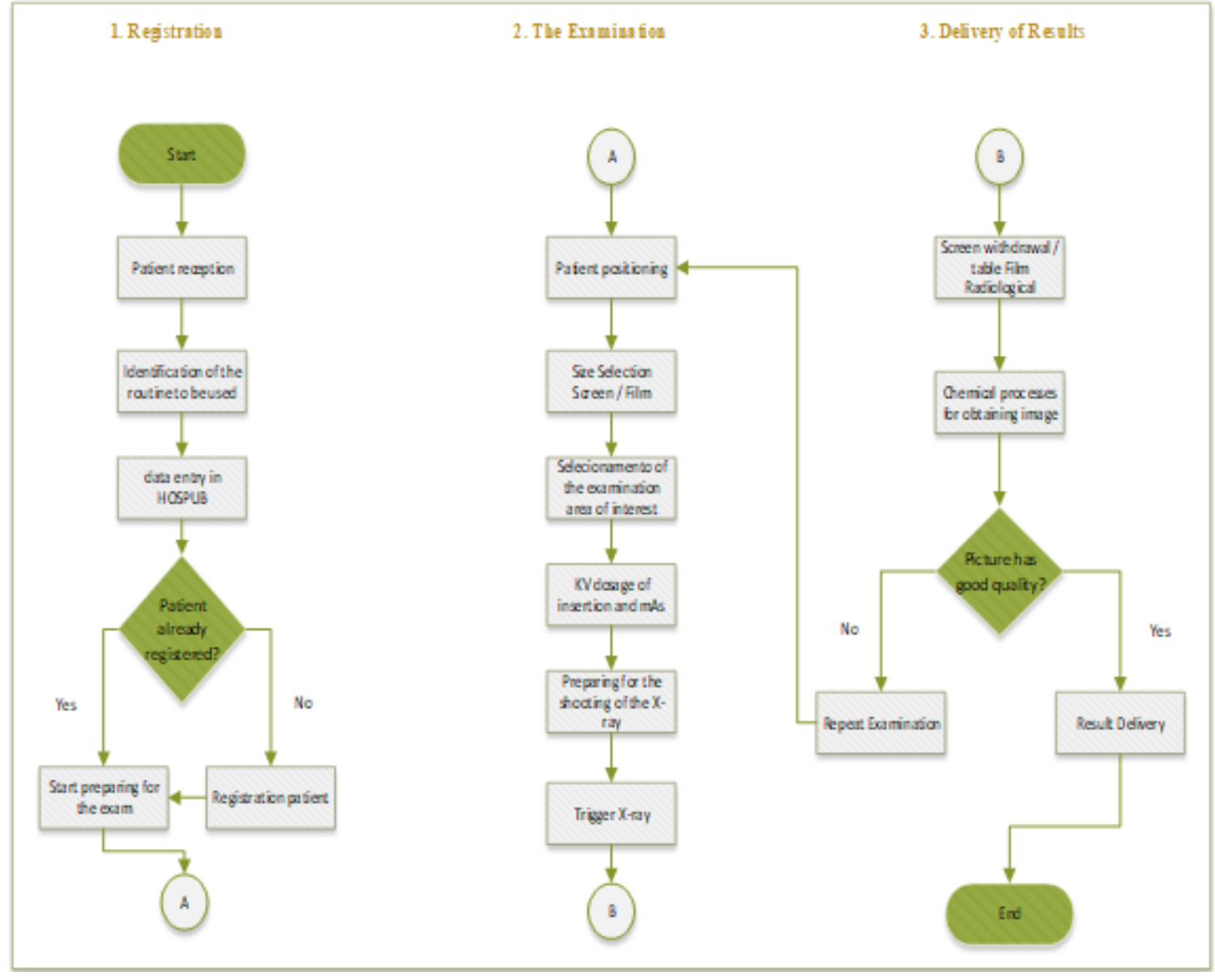




\begin{tabular}{|l|l|}
\hline \multicolumn{1}{|c|}{ Processes } & \multicolumn{1}{c|}{ Description of Processes } \\
\hline 1. Registration & $\begin{array}{l}\text { The registration process takes place from the moment the patient } \\
\text { arrives at the sector, it delivers the request to the examination then } \\
\text { is made the release of patient data in SUS database (National } \\
\text { Health System). }\end{array}$ \\
\hline Achievement & $\begin{array}{l}\text { At this stage the patient is positioned on the radiological table is } \\
\text { selected the screen size / film that will be used in the examination } \\
\text { and this is positioned in the radiology table in the examination area } \\
\text { of interest, after you select the area of interest of the requested } \\
\text { examination with the help light beams made that the technician } \\
\text { goes to the control panel where the dosages need be inserted to } \\
\text { obtain the image and finally fires the beam X-ray. }\end{array}$ \\
\hline 3. Result Delivery & $\begin{array}{l}\text { The third step, the result of delivery, is beginning right after } \\
\text { shooting the beam of X-ray, the technician will perform the removal } \\
\text { of screen / film radiographic table, this is taken to the darkroom } \\
\text { where will the chemical processes carried out by a machine } \\
\text { processor where they will be getting the picture, this is a quick } \\
\text { process that takes about two (2) minutes at the end of this process } \\
\text { the technical analyzes the quality of the image and makes the } \\
\text { release or re-examination. }\end{array}$ \\
\hline
\end{tabular}

Table 4: Contigency Theory in confrontation with practice in the study platform Source: Prepared by the authors

\subsection{Survey of procedures on the platform in study}

The diagnostic industry for image Hospital Unit study operates through demand ranging procedures performed daily, special procedures and finally procedures performed by seasonality, or according to the requests and medical referral to this sector. In comparison with the theory explained in theoretical review demonstrate in Table 5 below aspects of production that fall under this theory.

\begin{tabular}{|l|c|c|}
\hline \multicolumn{1}{|c|}{ Procedures } & \multicolumn{1}{|c|}{ Theory } & \multicolumn{1}{c|}{$\begin{array}{c}\text { Practical Application in the } \\
\text { Enterprise }\end{array}$} \\
\hline $\begin{array}{l}\text { Procedures performed } \\
\text { Diaries }\end{array}$ & $\begin{array}{c}\text { The organizational features have } \\
\text { an interaction with each other and } \\
\text { the environment. }\end{array}$ & $\begin{array}{l}\text { The diagnostic imaging industry works } \\
\text { with pre-determined processes, which } \\
\text { may change according to the daily } \\
\text { need. }\end{array}$ \\
\hline Special Procedures & $\begin{array}{c}\text { The organization is of systemic } \\
\text { nature, that is, it is an open } \\
\text { system. }\end{array}$ & $\begin{array}{c}\text { In specific cases such as external } \\
\text { examinations in the ICU (Intensive } \\
\text { Care Unit) as well as in emergency } \\
\text { works on demand serving specific } \\
\text { requests. }\end{array}$ \\
\hline $\begin{array}{l}\text { Procedures performed } \\
\text { by Seasonality }\end{array}$ & $\begin{array}{c}\text { Environmental features are the } \\
\text { independent variables, while the } \\
\text { organizational characteristics are } \\
\text { those dependent variables. }\end{array}$ & $\begin{array}{c}\text { In different periods is conducting } \\
\text { different tests, for example, on a } \\
\text { particular day of the week will be } \\
\text { carried out tests of postoperative } \\
\text { follow-up. }\end{array}$ \\
\hline
\end{tabular}

Table 5: Contingency Theory in confrontation with practice in Hospital Unit

Source: Prepared by the authors. 
By analyzing the procedures of the study platform it was observed that although the processes are quite varied, there is a regulation to achieve the same. However, one can see that the environment interferes significantly in the tests realization processes. In this sense, the Contingency Theory of acts so that the Hospital Unit meets specialized forms a distinguished audience keeping this in evidence as it relates to treatment of the target audience.

\subsection{Comparison of results between periods by kaizen method}

After the analyzes performed in the study platform in the period from 21 September 2015 to 21 October 2015, where the elements that could suffer interference from the Kaizen method were evaluated. improvements have been implemented in the sector that impacted the provision of service to patients, they are constantly being evaluated, so that way the activities are always carried out properly.

It is well known as a result of these improvements have impacted on the service provided by the sector, in Table 6 we observe a comparison between the activities that were previously carried out the improvements and how these are developed after implementation of these.

\begin{tabular}{|l|l|}
\hline \multicolumn{1}{|c|}{ Before Kaizen Application } & \multicolumn{1}{|c|}{ After the Kaizen Application } \\
\hline Warning light on a switch. & $\begin{array}{l}\text { Warning light on automatically when operating the X-ray } \\
\text { shooting. }\end{array}$ \\
\hline $\begin{array}{l}\text { Realization of room } \\
\text { undecorated exams. }\end{array}$ & $\begin{array}{l}\text { Examination room decorated with children's themes, which help } \\
\text { in maintaining the tranquility of the patients, thus preventing } \\
\text { these remain agitated which would result in poor quality of the } \\
\text { examination, leading to repetition of the same. }\end{array}$ \\
\hline $\begin{array}{l}\text { Use of poor quality films with } \\
\text { outdated due date. }\end{array}$ & Use of first-line films, within the validity period. \\
\hline $\begin{array}{l}\text { Outdated machinery, which is } \\
\text { analog operation. }\end{array}$ & $\begin{array}{l}\text { New machinery deployment, with digital operation, dramatically } \\
\text { improving the quality of examinations. }\end{array}$ \\
\hline
\end{tabular}

Table 6: Comparison of activities in the sector Source: Prepared by the authors

Thus it was observed that the deployment of the improvements brought visible improvements to work in the sector, highlighting main points the use of first-rate films and the installation of a new device, which together provide a higher quality in clinical exams.

\subsection{Measures for innovation in the process studied}

The innovation process for continuous improvement, are linked to search for knowledge of new technologies and the use of tools that enable the analysis continuously processes that occur on a daily basis in the sector, innovative processes are not fancy findings which arise as a new discovery, but a different way of treating known processes.

The tool used in this study was the PDCA cycle, which relies on development activities following a course of action along with checking of each activity undertaken, thus enabling the improvement of the process. Table 7 shows the way that the PDCA cycle can be applied in the development of radiology sector activities. 


\begin{tabular}{|l|l|}
\hline \multicolumn{1}{|c|}{ PDCA Cycle Processes } & \multicolumn{1}{c|}{ Desenvolvimento dos Procedimentos } \\
\hline 1. Set Goals & Set maximum number of repeat tests performed daily. \\
\hline 2. Establish Action Plan & $\begin{array}{l}\text { Define which processes will be applied to the amount of errors in } \\
\text { examinations is minimal. }\end{array}$ \\
\hline $\begin{array}{l}\text { 3. Conduct the action plan } \\
\text { execution }\end{array}$ & $\begin{array}{l}\text { Evaluating the implementation of what has been defined in the } \\
\text { action plan. }\end{array}$ \\
\hline $\begin{array}{l}\text { 4. Check the effectiveness of } \\
\text { the action plan }\end{array}$ & $\begin{array}{l}\text { Quantitative check of repeated tests, to assess the effectiveness } \\
\text { of the action plan. }\end{array}$ \\
\hline 5. Display of Results & $\begin{array}{l}\text { Through graphics, presentation of films of waste data for the } \\
\text { period of implementation of the action plan. }\end{array}$ \\
\hline $\begin{array}{l}\text { 6. Standardization of } \\
\text { procedures }\end{array}$ & $\begin{array}{l}\text { The results being satisfactory standard which was set in the } \\
\text { action plan. }\end{array}$ \\
\hline
\end{tabular}

Table 7: PDCA Application as innovative process Source: Prepared by the authors

The importance of having the PDCA cycle as a tool for assessing the waste of films by operation error becomes very important because it is the leading cause of burden for the sector, besides being the winner when it comes to complaint both patients, as the rest of the interdisciplinary team.

\section{CONCLUSIONS AND RECOMMENDATIONS}

This paper discussed the issue of the application of Kaizen in the Diagnostic Imaging Sector of a particular hospital unit located in the city of Porto Velho, Rondônia State Capital. Kaizen works in order to act in the continuous improvement of organizations, increasing the quality of services provided in the case study. Initially it was based on a literature Theory of Contingencies, which is directly related to the environmental conditions that can be differences in the development of the sector's activities.

Regarding the fulfillment of the objectives, as regards the question of the assessment of the radiological procedures realization processes had the perception of the variability of the same, being a specialized and personalized service because each patient requires some form of dedicated service. In this respect it demands specific care and at the same general time, the theory of contingencies fits best to this reality as it does not use just one look at the patient in question, but the look most suitable for each patient served.

On the other hand, the other specific objective aimed to make a comparison between two different times, the way in which the activities were developed in the sector before applying the Kaizen method and a second time, in order to calculate the improvements implemented in this. And in response to this comparison we obtained a significant improvement, especially when it comes to comfort and safety of patients to undergo the procedures with environmental themed decor, better safety equipment installation as well as the exchange of by radiological device, which is digital, providing a unique quality in the previous examinations with. And with respect to the elements of innovation has been the need for the daily monitoring of examinations of performing practices in the pursuit of a result of excellence. Regarding the issue of response to questioning realized how this industry works in order to improve the results of the tests can be said that the sector develops its activities striving for excellence in patient care. Today the industry develops the assessment and checking of the procedures adopted in this way seeking to improve continuously.

This task was essential to academic student who conducted the research as well as for the study platform researched aiming for identify possible actions which helped to improve the services provided by the sector. 


\section{REFERENCES LIST}

Assunção, D. S. (2013.) Kaizen Management Model and Its Application in Fertilizer Sector. 4 International Workshop Advances in Cleaner Production - Academic Work, São Paulo, SP. Available at: $<$ www.advancesincleanerproduction.net>. Accessed on November 3, 2015.

Chiavenato, I.. (2014). Introduction to the General Administration Theory. Editora Manole: Barueri,

Rosa, J. R. C. da, (2011). Quality management in a hospital radiology department: a study in the center of diagnostic imaging. Journal of Technological Innovation in Health, Brazil. Available at: <www.periodicos.ufrn.br>. Accessed on November 7, 2015.

Damas, K. F., (2012). Practical Treatise of radiology. São Caetano do Sul, SP: Yendis Publisher.

Dewes, F. et al. (2011). Environments and stimuli to support creativity applied to product innovation processes. Porto Alegre. Available at: <www.ufrgs.com.br>. Accessed on: November 18, 2015.

Gonçalves, A. A. (2012). Innovation in Health Services: Implementation of PACS at INCA. TAC, Rio de Janeiro, v. 2, no. 2, pp. 166-182, Jul./Dec. Available at: <www.ampad.org.br/tac>. Accessed on: November 18, 2015.

Mauricio, F. H.. (2013.) kaizen application to improvement in the manufacture of welded components in a metallurgical cooperative: a case study. XXXIII INTERNATIONAL CONFERENCE ON PRODUCTION ENGINEERING, Salvador, BA. Available at: <www.abepro.org.br>. Accessed on November 7, 2015.

Nascimento, A. F. G.. (2011). The use of the PDCA cycle methodology in the management of continuous improvement. Minas Gerais: ICAP. Available at: <www.icap.com.br>. Accessed on: November 13, 2015.

Pizzani, L. et al. (2012). The art of literature in search of knowledge. Rev. Dig. Dibli. . Ci. Inf, v.10, n.1. Available at: <www.sbu.unicamp.br>. Accessed: October 22, 2015.

Schimiguel, J.. (2011). Study and application of Kaizen in breaks reduction process: a case study. Anchieta University Center, Jundiaí, SP. Available at: <http://fatecid.com.br/>. Accessed on November 7, 2015. 